\title{
Evaluation of Kisspeptin Level in Non Obstructive Azoospermic Patients
}

\author{
BELAL A.E. MONTASER, M.D.*; ABDALLAH ATTIA, M.D.**; HOSAAM EL-DEEN YASSIN, M.D.** and \\ WALIED OSAMA, M.Sc.** \\ The Departments of Clinical Pathology* and Dermatology \& Andrology**, Faculty of Medicine, Menoufia University
}

\begin{abstract}
Background: Non-obstructive azoospermia is characterized by the complete absence of sperm in the ejaculate due to testicular failure. One of the genetic causes of non-obstructive azoospermia is the mutations in kisspeptin hormone and the kisspeptin hormone receptor (Kiss1r) genes. The level of kisspeptin hormone has been investigated in patients with non-obstructive azoospermia.
\end{abstract}

Aim of Study: The aim of the study was to evaluate the level of kisspeptin hormone (KISS1) in the serum of nonobstructive azoospermic males and its relation to fertility hormones (Follicle Stimulating Hormone (FSH), Luteinizing Hormone (LH), Testosterone and Prolactin).

Patients and Methods: This case control study was done from August 2017 to August 2018 \& included 25 nonobstructive azoospermic patients \& 25 cases of age matched healthy fertile control subjects. After full history taking and general and local examination, Kisspeptin level was measured using ELISA. Follicle Stimulating Hormone (FSH), Luteinizing Hormone (LH), Testosterone (T) and Prolactin hormone (PRL) were also measured.

Results: The mean value of kisspeptin hormone was significantly lower in cases $(6.30 \pm 2.07 \mathrm{ng} / \mathrm{ml})$ than controls $(36.70 \pm 9.64 \mathrm{ng} / \mathrm{ml})$. The patients had significant high level of FSH ( $p$-value $<0.001)$, high level of LH ( $p$-value $=0.001)$ and low level of Testosterone $(p$-value $=0.022)$. No correlation was found between plasma kisspeptin levels and (FSH, LH, Testosterone \& Prolactin).

Conclusion: Kisspeptin level is lower in non-obstructive azoospermic infertile males than the fertile controls, so it might be used as a diagnostic tool for infertility and treatment of infertility disorders in patients proved to have a low level of kisspeptin hormone.

Key Words: Follicle stimulating hormone - Kisspeptins Luteinizing hormone - Male infertility - Nonobstructive azoospermia - Testosterone.

Correspondence to: Dr. Belal Montaser, E-Mail: drbelalmontaser@yahoo.com

\section{Introduction}

MALE infertility is a widespread problem as $10 \%$ to $20 \%$ of infertile males are found to be azoospermic. Azoospermia, defined as complete absence of sperms in the ejaculate, is classically categorized into non-obstructive or obstructive according to the etiology of azoospermia [1]

Obstructive azoospermia is defined as the absence of spermatozoa in the ejaculate despite normal spermatogenesis due to obstruction to the flow of semen [2]. Non-obstructive azoospermia is characterized by the complete absence of sperm in the ejaculate due to testicular failure. There are numerous causes of non-obstructive azoospermia such as genetic and chromosomal abnormalities, cryptorchidism, hormonal abnormality, trauma, exogenous testosterone supplementation \& varicocele [3]. The extent of improvement in semen parameters correlates with grade of varicocele treated with the biggest improvement seen in grade 3 varicocele

One of the genetic causes of non-obstructive azoospermia is the mutations in kisspeptin hormone and the kisspeptin hormone receptor genes, which result in reproductive dysfunction in humans and male infertility [5]. Kisspeptins, which are family of peptide hormones, have recently been identified as a key neuroendocrine regulator of reproduction and are essential for the initiation of human puberty and maintenance of adult reproduction. They regulate the hypothalamic-Pituitary-Gonadal (HPG) axis by controlling Gonadotropin-Releasinghormone $(\mathrm{GnRH})$ secretion [6] . Loss and mutation of the kisspeptin signaling causes hypogonadotrophic hypogonadism in humans [7]. 
Kisspeptin levels were observed significantly lower in the infertile as compared to the fertile males, indicating that the kisspeptin might be associated with the fertility problems in males so its level can be used as diagnostic tool in infertility disorders and for better evaluating of azoospermic patient [8]

This study aimed to assess the level of kisspeptin hormone in serum of non-obstructive azoospermic males and to study its correlation to the main hormones of reproduction (follicle stimulating hormone, luteinizing hormone, testosterone \& prolactin).

\section{Patients and Methods}

We designed a case control study included 50 male subjects. Subjects were divided into two groups, a case group composed of 25 cases of infertile non-obstructive azoospermic patients and a control group composed of 25 age-matched healthy fertile males. They were recruited from the Andrology Clinic of Menoufia University Hospital, Menoufia, Egypt from August 2017 to August 2018. The study was approved by Ethical Committee of Menoufia Faculty of Medicine and an informed consent was taken from each subject included in the study.

Inclusion criteria for cases were male patients with primary infertility known to be non-obstructive azoospermia while exclusion criteria included obstructive azoospermic patients diagnosed or suspected either clinically or by investigation such as azoospermia with full epididymis, azoospermia with absent vas and Azoospermia with Fructose ve in semen.

All subjects were obtained for full history taking, proper general and genital examination and laboratory investigations in the form of semen analysis of at least 2 semen samples achieved by masturbation after a period of sexual abstinence of 3 days whose results were evaluated according to criteria recommended by WHO in 2010 and evaluation of serum levels of FSH, LH, prolactin and testosterone by analysis of non-fasting venous blood samples collected from the subjects using disposable sterile syringes from which serum was separated through centrifugation at $1600 \mathrm{xg}$ and stored at $-80^{\circ} \mathrm{C}$ for subsequent hormonal analysis. Follicle Stimulating Hormone (FSH), Luteinizing Hormone $(\mathrm{LH})$, testosterone and prolactin were quantitatively determined using (monoclonal antibody, immunoflurecent assay vidas, biomerieux S.A, France) kits.
The subjects in both groups also were obtained for quantitative evaluation of serum kisspeptin by Enzyme Linked Immunosorbent Assay (ELISA). The essential reagents required for an imunoenzymometric assay include high affinity and specificity antibodies (enzyme conjugated and immobilized) with different and distinct epitope recognition, in excess and native antigen. In this procedure, the immobilization takes place during the assay at the surface of a microplate well through the interaction of streptavidin (s.Avidin) coated on the well and exogenously added biotinylated monoclonal antiKisspeptin antibody (Ab) (Phoenix Pharmaceuticals, Inc, California, USA, Product code: EK-04856, Human Kisspeptin). An interaction was achieved between a labeled antibody and a serum containing the native antigen in the form of a globule sandwich complex [9]. The minimum detectable concentration was $0.15 \mathrm{ng} / \mathrm{ml}$.

\section{Statistical analysis:}

Results were statistically analyzed by SPSS Version 20 (SPSS Inc., Chicago, IL, USA).

Two types of statistics were done:

Descriptive: E.g., percentage (\%), mean and standard deviation (S).

Analytical: Student's $t$-test, Mann-Whitney test, Chi-Squared $\left(\chi^{2}\right)$, Fisher's exact test, Spearman and Pearson's Correlation analysis were used.

\section{Results}

The patients and controls were age matched. There was significant decrease in both right $(p$-value $=0.010)$ and left testicular volume $(p$ value $=0.011)$ in cases in comparison to controls (Table 1).

The mean value of kisspeptin hormone was significantly lower in cases $(6.30 \pm 2.07 \mathrm{ng} / \mathrm{ml})$ than controls $(36.70 \pm 9.64 \mathrm{ng} / \mathrm{ml})$. Kisspeptin was highly significantly decreased in non-obstructive azoospermic patients ( $p$-value $<0.001)$ (Table 2) and Fig. (1).

The patients had significant high level of FSH ( $p$-value $<0.001)$, high level of LH $(p$-value $=0.017)$, and low level of testosterone $(p$-value $=0.018)$. Although prolactin was higher in cases than controls, it was not significant (Table 3) and Fig. (2).

By studying the correlation between kisspeptin and age, FSH, LH, prolactin and testosterone the study showed that there were no significant correlation between age, FSH, LH, prolactin and kisspeptin (Table 4). 
Table (1): Age and local examination of the studied groups.

\begin{tabular}{|c|c|c|c|c|c|c|}
\hline \multirow{3}{*}{ Variables } & \multicolumn{4}{|c|}{ Groups } & \multirow{3}{*}{$\begin{array}{l}\text { Test of } \\
\text { signifi- } \\
\text { cance }\end{array}$} & \multirow{3}{*}{$\begin{array}{c}p- \\
\text { value }\end{array}$} \\
\hline & \multicolumn{2}{|c|}{$\begin{array}{l}\text { Patients } \\
(\mathrm{N}=25)\end{array}$} & \multicolumn{2}{|c|}{$\begin{array}{l}\text { Controls } \\
(\mathrm{N}=25)\end{array}$} & & \\
\hline & $\mathrm{n}$ & $\%$ & $\mathrm{n}$ & $\%$ & & \\
\hline $\begin{array}{l}\text { Age }(Y): \\
\quad \mathrm{X} \pm \mathrm{SD}\end{array}$ & 31.5 & \pm 9.12 & 31.2 & $4 \pm 6.31$ & $t=0.12$ & 0.900 \\
\hline $\begin{array}{l}\text { Right testicular volume: } \\
\text { Small } \\
\text { Normal }\end{array}$ & $\begin{array}{l}7 \\
18\end{array}$ & $\begin{array}{l}28.0 \\
72.0\end{array}$ & $\begin{array}{l}0 \\
25\end{array}$ & $\begin{array}{l}0.0 \\
100.0\end{array}$ & $\begin{array}{l}\text { Fisher's } \\
\text { exact } \\
8.14\end{array}$ & $0.010^{*}$ \\
\hline $\begin{array}{l}\text { Left testicular volume: } \\
\text { Small or absent } \\
\text { Normal }\end{array}$ & $\begin{array}{l}0 \\
25\end{array}$ & $\begin{array}{l}0.0 \\
100.0\end{array}$ & $\begin{array}{l}6 \\
19\end{array}$ & $\begin{array}{l}24.0 \\
76.0\end{array}$ & $\begin{array}{l}\text { Fisher's } \\
\text { exact } \\
6.85\end{array}$ & $0.011 *$ \\
\hline $\begin{array}{ll}* & : \text { Significant. } \\
\mathrm{N} & : \text { Number. } \\
\mathrm{X} & : \text { Mean. } \\
\mathrm{SD} & : \text { Standard Deviation. }\end{array}$ & & $\begin{array}{l}t \\
\chi^{2} \\
p_{\%}\end{array}$ & $\begin{array}{l}\text { Stu } \\
\text { Chi } \\
\text { Pro } \\
\text { Per }\end{array}$ & $\begin{array}{l}\text { lent's } t \text {-t } \\
\text { Squared } \\
\text { ability. } \\
\text { entage }\end{array}$ & & \\
\hline
\end{tabular}

Table (2): Kisspeptin level of the studied groups.

\begin{tabular}{|c|c|c|c|c|}
\hline \multirow[b]{2}{*}{ Kisspeptin } & \multicolumn{2}{|c|}{ Groups } & \multirow[b]{2}{*}{$\begin{array}{c}t- \\
\text { test }\end{array}$} & \multirow[b]{2}{*}{$\begin{array}{c}p \text { - } \\
\text { value }\end{array}$} \\
\hline & $\begin{array}{c}\text { Patients } \\
(\mathrm{N}=25) \\
\mathrm{X} \pm \mathrm{SD}\end{array}$ & $\begin{array}{c}\text { Controls } \\
(\mathrm{N}=25) \\
\mathrm{X} \pm \mathrm{SD}\end{array}$ & & \\
\hline Kisspeptin & $6.30 \pm 2.07$ & $36.70 \pm 9.64$ & 15.40 & $<0.001 *$ \\
\hline $\begin{array}{l}*: \text { Signific } \\
\mathrm{N}: \text { Number } \\
\mathrm{X}: \text { Mean. }\end{array}$ & & $\begin{array}{ll}\mathrm{SD} & : \text { Sta } \\
t & : \text { Stu } \\
p & : \text { Pro }\end{array}$ & $\begin{array}{l}\text { d deviat } \\
\text { 's } t \text {-test. } \\
\text { lity. }\end{array}$ & \\
\hline
\end{tabular}

Table (3): Hormonal assessment of the studied groups.

\begin{tabular}{|c|c|c|c|c|}
\hline \multirow[b]{2}{*}{ Hormones } & \multicolumn{2}{|c|}{ Groups } & \multirow{2}{*}{$\begin{array}{c}\text { Mann- } \\
\text { Whitney } \\
\text { test }\end{array}$} & \multirow[b]{2}{*}{$\begin{array}{c}p- \\
\text { value }\end{array}$} \\
\hline & $\begin{array}{l}\text { Controls } \\
(\mathrm{N}=25) \\
\mathrm{X} \pm \mathrm{SD}\end{array}$ & $\begin{array}{l}\text { Patients } \\
(\mathrm{N}=25) \\
\mathrm{X} \pm \mathrm{SD}\end{array}$ & & \\
\hline FSH & $5.81 \pm 3.03$ & $21.49 \pm 13.51$ & 5.05 & $<0.001^{*}$ \\
\hline $\mathrm{LH}$ & $5.61 \pm 1.98$ & $10.09 \pm 6.64$ & 2.38 & $0.017 *$ \\
\hline Prolactin & $9.08 \pm 4.22$ & $12.39 \pm 8.49$ & 1.46 & 0.142 \\
\hline Testosterone level & $5.18 \pm 1.85$ & $3.88 \pm 2.21$ & 2.36 & $0.018^{*}$ \\
\hline $\begin{array}{ll}* & : \text { Significant. } \\
\text { FSH } & : \text { Follicle Stim } \\
\text { LH } & : \text { Luteinizing I } \\
\mathrm{N} & : \text { Number. } \\
\overline{\mathrm{X}} & : \text { Mean. }\end{array}$ & \multicolumn{2}{|r|}{$\begin{array}{l}\text { SD } \\
\chi^{2} \\
p_{\%}\end{array}$} & \multicolumn{2}{|c|}{$\begin{array}{l}\text { Standard Deviation. } \\
\text { Chi-squared. } \\
\text { Probability. } \\
\text { Percentage. }\end{array}$} \\
\hline
\end{tabular}

Table (4): Correlation between kisspeptin level and age and other hormones.

\begin{tabular}{|c|c|c|c|c|c|}
\hline & \multirow{3}{*}{ Parameters } & \multicolumn{4}{|c|}{ Kisspeptin } \\
\hline & & \multicolumn{2}{|c|}{$\begin{array}{l}\text { Controls } \\
(\mathrm{N}=25)\end{array}$} & \multicolumn{2}{|c|}{$\begin{array}{c}\text { Patients } \\
(\mathrm{N}=25)\end{array}$} \\
\hline & & $r$ & $p$-value & $r$ & $p$-value \\
\hline & Age & -0.198 & 0.343 & -0.032 & 0.880 \\
\hline & $\mathrm{FSH}$ & 0.079 & 0.708 & 0.152 & 0.469 \\
\hline & $\mathrm{LH}$ & 0.179 & 0.393 & -0.314 & 0.126 \\
\hline & Prolactin & 0.314 & 0.154 & -0.005 & 0.983 \\
\hline & Testosterone & -0.126 & 0.549 & -0.107 & 0.611 \\
\hline$*$ & \multicolumn{5}{|l|}{ Significant. } \\
\hline FSH & \multicolumn{5}{|c|}{ Follicle Stimulating Hormone. } \\
\hline LH & \multicolumn{5}{|c|}{ Luteinizing Hormone. } \\
\hline$r$ & \multicolumn{5}{|c|}{ Spearman and Pearson's correlation analysis. } \\
\hline$p$ & Probability. & & & & \\
\hline
\end{tabular}

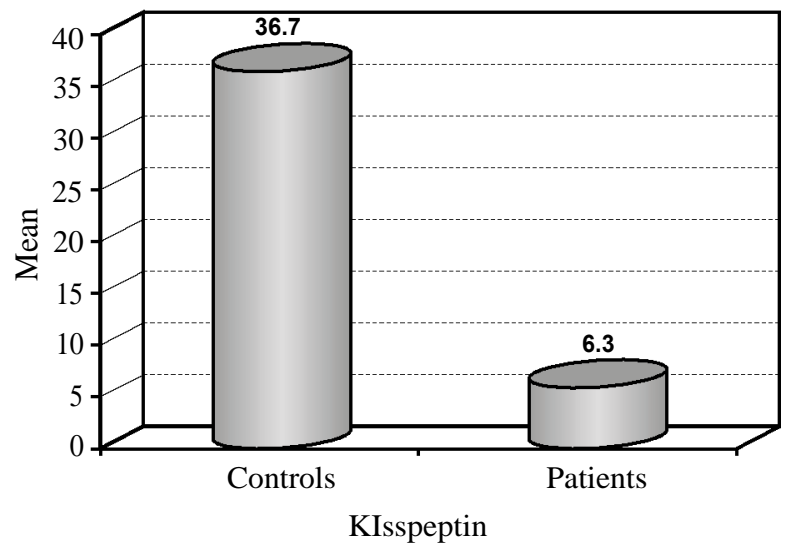

Fig. (1): Kisspeptin level of the studied groups.

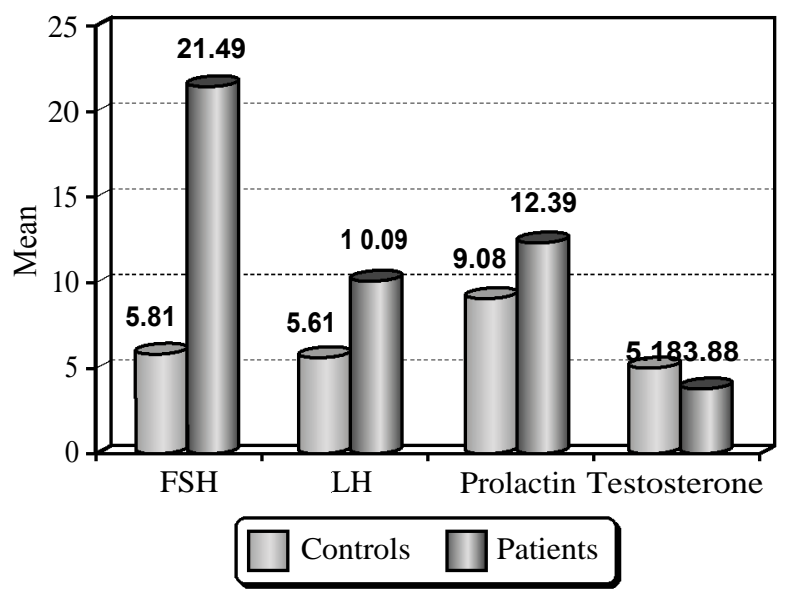

Fig. (2): Hormonal assessment of the studied groups.

\section{Discussion}

Non-Obstructive Azoospermia (NOA) is diagnosed in approximately $10 \%$ of infertile men. NOA accounts for approximately $60 \%$ of men with azoospermia and represents the most severe form of male factor infertility [10].

Hormone analysis forms the cornerstone of the further evaluation and management of NOA. The American Urological Association recommends an estimation of serum FSH and testosterone as the initial hormonal assessment. Additional hormone analysis, including Luteinizing Hormone (LH), estradiol and prolactin evaluations, is performed based on the likelihood of their abnormality and potential impact on management [11].

The kisspeptins, which are family of peptide hormones, have been shown to play a critical role in the regulation of the hypothalamic-pituitarygonadal axis, thus in turn influencing fertility and reproduction [12]. 
Some studies were carried out to determine the role of kisspeptin in the regulation of the reproductive axis. However, information regarding the kisspeptin concentration in infertile males was lacking. Ramzan et al., [5] was the first study to measure the serum kisspeptin in infertile males.

In the current study the cases and controls were age matched, the level of kisspeptin hormone was measured using ELISA technique and the mean value of it was significantly lower in cases (6.30 \pm $2.07 \mathrm{ng} / \mathrm{ml})$ than controls $(36.70 \pm 9.64 \mathrm{ng} / \mathrm{ml})$.

In consistent with that; Ramzan et al., [5] measured the kisspeptin in infertile males and age matched fertile controls. In fertile subjects, kisspeptin levels were observed significantly higher $(p$ $<0.001)$ [23.32 (11.08-36.55)], as compared with infertile azoospermic [4.41 (2.69-6.82)] males.

Also kotani et al., [13] stated that kisspeptin levels of fertile (control) males are significantly increased in comparison to males with isolated hypogonadotropic hypogonadism $(12.3 \pm 2.5 \mathrm{fmol} / \mathrm{ml}$ (mean $\pm \mathrm{SD}$ ) vs $6.0 \pm 0.5 \mathrm{fmol} / \mathrm{ml}$ respectively).

The low level of kisspeptin is interpreted that in functional azoospermic patients there may be decrease expression of Kisspeptin mRNA in the hypothalamus which will lead to low level of kisspeptin and as the kisspeptin is recently considered a main regulator of hypothalamic pituitary gonadal axis and in functional azoospermic patients this axis is impaired in one way or another which will affect and impair the secretion of kisspeptin.

In the current study correlation between kisspeptin and FSH, LH, Testosterone \& Prolactin hormones was measured and showed no correlation between plasma kisspeptin levels and FSH, LH, Testosterone \& Prolactin.

This is conflicted with other studies, which stated that kisspeptin is a powerful stimulator of LH and FSH release which will lead to testosterone production $[\mathbf{1 4 , 1 5}]$

This can be explained that theoretically its level should be correlated with FSH \& LH, however no enough studies were done studying the real correlation between kisspeptin and other fertility hormones in infertile men so information regarding this issue is lacking.

Both testicular volumes were measured clinically. In cases, right and left testicular volume was significantly less than its volume in control.
This is consistent with Arai et al., [16] who stated that testicular volume has a direct correlation with semen profiles, and so it is significantly decreased in azoospermic patients.

In the current study the level of FSH and LH were significantly elevated and testosterone was significantly decreased.

This is consistent with Gudeloglu and Parekattil [17]. Who stated that in primary hypogonadism, normal or elevated LH and FSH levels accompanied with low serum testosterone levels.

This is explained that most of our cases were hypergonadotrophic hypogonadism with high FSH, LH and decreased testosterone.

\section{Conclusion:}

As the kisspeptin level is lower in infertile males than the fertile controls, it might be used as a diagnostic tool for infertility and treatment of infertility disorders in patients proved to have a low level of kisspeptin hormone but more studies are needed on larger scales.

\section{References}

1- GUDEMAN S.R., TOWNSEND B., FISCHER K., WALTERS R.C. and CRAIN D.: Etiology of azoospermia in a military population. J. Urol., 193: 1318-21, 2015.

2- BAKER K. and SABANEGH E. Jr.: Obstructive azoospermia reconstructive techniques and results. Clinics, 68: 61-73, 2013.

3- TISEO B.C., HAYDEN R.P. and TANRIKUT C.: Surgical management of nonobstructive azoospermia. Asian J. Urol., 2: 85-91, 2015.

4- OMAR A.A., GREDA H.S. and ABOULFOTOH M.S.: Study of inguinal versus retroperitoneal approach in the treatment of varicocele. M.M.J., 28: 1-4, 2015.

5- RAMZAN M.H., RAMZAN M., RAMZAN F., WAHAB F., JELANI M., KHAN M.A., et al.: Insight into the serum kisspeptin levels in infertile males. Arch. Iran Med., 18: 12-7, 2015.

6- SKORUPSKAITE K., GEORGE J.T. and ANDERSON R.A.: The kisspeptin-GnRH pathway in human reproductive health and disease. Hum. Reprod Update, 20: 485500, 2014.

7- NOVAIRA H.J., SONKO M.L., HOFFMAN G., KOO Y., KO C., WOLFE A., et al.: Disrupted kisspeptin signaling in GnRH neurons leads to hypogonadotrophic hypogonadism. Mol. Endocrinol., 28: 225-38, 2014.

8- CLARKE H., DHILLO W.S. and JAYASENA C.N.: Comprehensive Review on Kisspeptin and Its Role in Reproductive Disorders. Endocrinol. Metab. (Seoul), 30: 124-41, 2015. 
9- PORSTMANN T. and KIESSIG S.T.: Enzyme Immunoassay Techniques, an Overview. J. Immunol. Methods, 150: 5-21, 1992.

10- HAMADA A.J., ESTEVES S.C. and AGARWAL A.A.: Comprehensive review of genetics and genetic testing in azoospermia. Clinics. 2013; 68: 39-60.

11- KUMAR R.: Medical management of non-obstructive azoospermia. Clinics (Sao Paulo), 68: 75-9, 2013.

12- HAMEED S., JAYASENA C.N. and DHILLO W.S.: Kisspeptin and fertility. J. Endocrinol., 208: 97-105, 2011.

13- KOTANI M., KATAGIRI F. and HIRAI T.: Plasma kisspeptin levels in male cases with hypogonadism. Endocr. J., 61: 1137-40, 2014.

14- GOTTSCH M.L., CUNNINGHAM M.J., SMITH J.T., POPA S.M., ACOHIDO B.V., CROWLEY W.F., et al.:
A role for kisspeptins in the regulation of gonadotropin secretion in the mouse. Endocr., 145: 4073-7, 2004.

15- SHAHAB M., MASTRONARDI C., SEMINARA S.B., CROWLEY W.F., OJEDA S.R. and PLANT T.M.: Increased hypothalamic GPR54 signaling: A potential mechanism for initiation of puberty in primates. Proc. Natl. Acad. Sci. USA, 102: 2129-34, 2005.

16- ARAI T., KITAHARA S., HORIUCHI S., SUMI S. and YOSHIDA K.: Relationship of testicular volume to semen profiles and serum hormone concentrations in infertile Japanese males. Int. J. Fertil Womens Med., 43: 40-7, 1998.

17- GUDELOGLU A. and PAREKATTIL J.S.: Update in the evaluation of the azoospermic male. Clinics (Sao Paulo), 68: 27-34, 2013.

\title{
تقييه مستوى الكيسبيتين فى مرضى إنعلام النطاف فير الإنسدادى
}

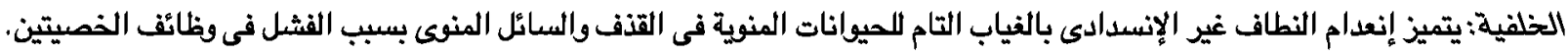

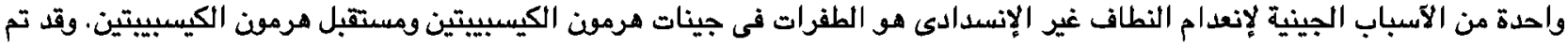

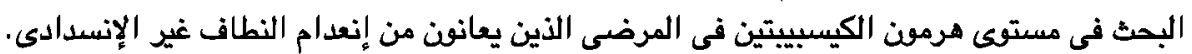

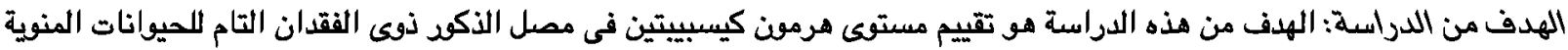 \\ غير الإنسدادى وعلاقته بهرمونات الخصوبة (هرمون تحفيز التحوصل، الهرمون اللوتينى، التستوستيرون والبرونلاكتين).

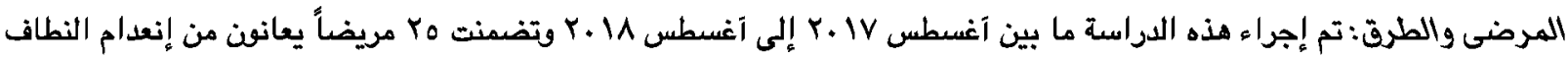

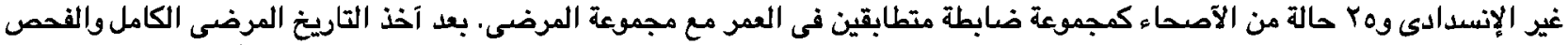

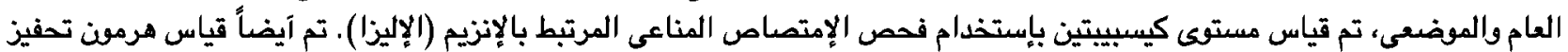

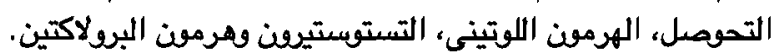

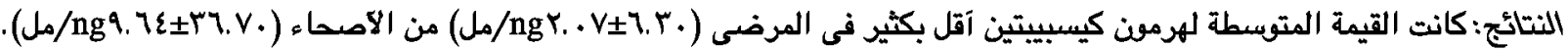

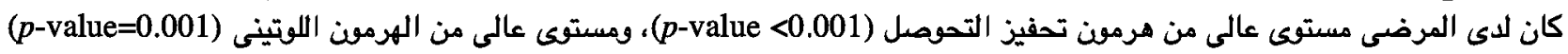

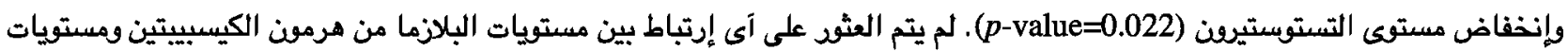 \\ هرمونات الخصوبة هرمون تحفيز التحوصل، الهرمن اللوتينى، التستوستيرنئ وهرمون البرولاكتين. \\ الخلاصة: إن مستوى كيسبييتين آقل لدى الرجال المصابين بالعقم وإنعدام النطاف غير الإنسدادى مقارنة بالآصحاء، لذلك يمكن إستخدامهيه \\ كاداة تثخيصية العقم وعلاج إضطرابات العقم عند المرضى الذين ثبت آن لديهم هستوى منخفض من هرمون الكيسبييتين.
}

